\title{
Impact on Knowledge Gain through Farmer Field School (FFS) on Eco-Friendly Crop Management in Paddy
}

\author{
G. Porkodi* and S. Kannan \\ Krishi Vigyan Kendra, Vridhachalam, Cuddalore District, TamilNadu, India \\ *Corresponding author
}

\section{Keywords}

Paddy, Eco friendly

Management,

Knowledge and

Adoption

Article Info

Accepted:

15 March 2020

Available Online:

10 April 2020

\section{A B S T R A C T}

Farmer Field School (FFS) is a participatory and interactive approach to social learning. It is an approach that puts together set of principles and techniques meant to systematically enhance farmers' abilities to investigate, analyze, innovate and learn improved farming practices. The FFS provide an opportunity for farmers to learn together and test and adapt practices, using practical, hands-on methods of discovery learning that emphasize observation, discussion, analysis and collective decision making. The present study on access the impact of knowledge gain through Farmer Field School (FFS) on eco-friendly crop management in paddy. The profile analysis of FFS farmers indicated that majority of them were middle aged, with medium farming experience, medium farm size, high level of extension contact, high level of innovativeness, high level of mass media exposure, medium level of scientific orientation, risk orientation and high level of training undergone. FFS farmers possessed high level of Knowledge when compared to Non FFS farmers. From the demonstrations, an average yield of $66.50 \mathrm{q} \mathrm{ha}^{-1}$ was recorded in FFS participated farmers as against $62.25 \mathrm{q} \mathrm{ha}^{-1}$ from non-FFS farmers (farmers practice). Obviously, this can be attributed due to impact of FFS. The B:C ratio was highest in demonstrated plot (1.86) when compared with farmer practice (1.65). Thus, the present extension delivery system can be supported through taking demonstrations by using FFS methodology as a successful extension approach.

\section{Introduction}

The Farmer Field School (FFS) approach is a participatory methodology of technology development and dissemination, which gives the farmer an opportunity to learn through practical field activities. The special feature of FFS is field based learning and acts as a primary venue of learning for farmers. The FFS programme also empowers the farmers to take economically viable decisions by adopting the practices of Integrated Crop Management (ICM). The aim of the FFS is to build the capacity of farmers to analyze their production systems, identify problems, test possible solutions and eventually adopt the practices that is most suitable to their farming system. FFS approach is designed to create capacities in farmers so that they can analyze their productive systems, identify their 
problems, test solutions and choose the most appropriate operation according to their agricultural system. Consequently, their productivity and profitability will increase (Luther et al., 2005). Training in FFS seeks to assist farmers to develop their ability to make critical and informed decisions that will render their crop production systems more productive, profitable and sustainable (Khisa and Heinemann, 2005). For the success of any programme, there should be a periodical appraisal and evaluation of what is being done, so that suitable changes can be made for effective functioning. Since Krishi Vigyan Kendra, Cuddalore organized farmer field schools on eco-friendly crop management in paddy.

\section{Materials and Methods}

The Krishi Vigyan Kendra, Cuddalore District, Tamil Nadu conducted Farmers Field School (FFS) at Sathakudal village in rice ecosystem of Vridhachalam block for ecofriendly crop management in paddy in a group of 30 farmers. It was a field based learning experience for the full cropping season, with 14 meeting times with an approximate length of three to four hours per meeting so that farmers could observe and analyse the dynamics of the rice field ecology across a full season. Field School plots received two treatments. A set of plots, which was designated as ecofriendly crop management in paddy and another set as designated as local treatment (farmer practice). The following technologies were demonstrated in FFS,

Seed treatment with biofertilzers and bio control agents

Use of green manure and green leaf manure

Use of vermicompost

Leaf colour chart

Foliar spray of Pseudomonas fluorescens @ $0.2 \%$ at 20 and 40 DAP

Preparation of panchagavya and spray
Spray of neem oil and Neem seed kernal extract

Setting of yellow sticky trap and pheromone trap

Use of egg parasites Trichogramma chilonis for leaf folder management

The primary difference between the two was that the non-IPM fields received an imbalanced dosage of nutrient treatment as well as chemical pesticide sprays while in the IPM fields farmers applied a balanced fertilizer treatment (NPK) with integrated nutrient management, planted at lower densities with wider spacing and need based botanical as well as bio pesticide application. Due to the importance of the field study plots in the learning process, the Field School meeting place was usually close to the field study plots under shaded trees.

\section{Data collection}

The data pertaining to the general information of paddy farmers, holding size, cropping pattern, costs and returns, plant protection measures used, awareness of farmers with regard to the toxicity level of pesticides, safety procedures followed during application of plant protection chemicals (PPCs), experience of farmers with regard to the health hazards after PPC application and endemics observed in the region were collected by personal interview method using a pre tested schedule designed for the study.

\section{Activities}

Each meeting of FFS consisted of the following set pattern of activities:

1. Agro-ecosystem field observation, analysis and presentations;

2. Discussion on special topics

3. Group dynamics. 


\section{Results and Discussion}

Knowledge levels in the FFS were $64 \%$ and 94\% for pre knowledge and post knowledge respectively. The Knowledge spreads in the FFS were presented in table 1 and 2. The impacts of FFS, the farmers were knowledge about seed treatment, integrated nutrient management, integrated pest management and bio control agent.

To assess the impact of FFS on yield, cost benefit ratio, pest and disease incidence were computed for the demonstrated plot in FFS and the results compared with control plots (Table 3). Average yield recorded in paddy under FFS farmers $66.50 \mathrm{q} \mathrm{ha}^{-1}$ which was more than non-FFS farmers $\left(62.25 \mathrm{q} \mathrm{ha}^{-1}\right)$.
The results indicated that the FFS demonstrations gave good impact over the farming community of Cuddalore district as they were motivated by the new agricultural technologies applied in the demonstration plots. The B:C ratio was highest in demonstration plot (1.86) when compared with farmer practice (1.65).

The pest and disease incidence were less in FFS demonstration plot when compared with non-FFS demonstration plot. Farmer Field Schools (FFS) can contribute to increasing farmers' skills and lowering insecticide use in rice (Tripp et al., 2005). FFS participants had significantly better adoption of biological control than the non- FFS farmers (Bunyatta et al., 2006).

Table.1 Knowledge spread in the FFS

\begin{tabular}{|c|c|c|c|c|}
\hline $\begin{array}{l}\text { Sl. } \\
\text { No. }\end{array}$ & Category & $\begin{array}{c}\text { Pre } \\
\text { knowledge }\end{array}$ & $\begin{array}{c}\text { Post } \\
\text { knowledge }\end{array}$ & Remarks \\
\hline 1 & $\begin{array}{l}\text { Seed treatment with } \\
\text { biofertilzers and bio control } \\
\text { agents }\end{array}$ & Partly known & Fully known & Now using \\
\hline 2 & $\begin{array}{l}\text { Use of green manure and } \\
\text { green leaf manure }\end{array}$ & Partly known & Fully known & Now using \\
\hline 3 & Use of vermicompost & Partly known & Fully known & $\begin{array}{l}\text { Now using upon } \\
\text { availability }\end{array}$ \\
\hline 4 & Leaf colour chart & Partly known & Fully known & Now using \\
\hline 5 & $\begin{array}{l}\text { Foliar spray of Pseudomonas } \\
\text { fluorescens @ } 0.2 \% \text { at } 20 \text { and } \\
40 \text { DAP }\end{array}$ & Not awared & Fully known & $\begin{array}{l}\text { Now using upon } \\
\text { availability }\end{array}$ \\
\hline 6 & $\begin{array}{l}\text { Preparation of panchagavya } \\
\text { and spray }\end{array}$ & $\begin{array}{l}\text { Awared but } \\
\text { not used }\end{array}$ & Fully known & Now using \\
\hline 7 & $\begin{array}{l}\text { Spray of neem oil and Neem } \\
\text { seed kernal extract }\end{array}$ & $\begin{array}{l}\text { Awared but } \\
\text { not used }\end{array}$ & Fully known & $\begin{array}{l}\text { Now using upon } \\
\text { availability }\end{array}$ \\
\hline 8 & $\begin{array}{l}\text { Setting of yellow sticky trap } \\
\text { and pheromone trap }\end{array}$ & $\begin{array}{l}\text { Not fully } \\
\text { awared }\end{array}$ & Fully known & $\begin{array}{l}\text { Availability of the } \\
\text { quality material is } \\
\text { difficult }\end{array}$ \\
\hline 9 & $\begin{array}{l}\text { Use of egg parasites } \\
\text { Trichogramma chilonis for } \\
\text { leaf folder management }\end{array}$ & $\begin{array}{l}\text { Not fully } \\
\text { awared }\end{array}$ & Fully known & $\begin{array}{l}\text { Availability of the } \\
\text { quality material is } \\
\text { difficult }\end{array}$ \\
\hline
\end{tabular}


Table.2 Item wise analysis of knowledge and adoption of FFS participants and FFS Non-participants

\begin{tabular}{|c|c|c|c|c|c|}
\hline \multirow{2}{*}{$\begin{array}{l}\text { Sl. } \\
\text { No }\end{array}$} & \multirow[t]{2}{*}{ Item } & \multicolumn{2}{|c|}{ Knowledge } & \multicolumn{2}{|c|}{ Adoption } \\
\hline & & $\begin{array}{c}\text { FFS } \\
\text { participants }\end{array}$ & $\begin{array}{c}\text { Non- } \\
\text { participants }\end{array}$ & $\begin{array}{c}\text { FFS } \\
\text { participants }\end{array}$ & $\begin{array}{c}\text { Non- } \\
\text { participants }\end{array}$ \\
\hline 1 & $\begin{array}{l}\text { Seed treatment with } \\
\text { biofertilzers and bio } \\
\text { control agents }\end{array}$ & 92.343 & 85.67 & 83.33 & 76.67 \\
\hline 2 & $\begin{array}{l}\text { Use of green manure and } \\
\text { green leaf manure }\end{array}$ & 86.67 & 83.33 & 86.67 & 81.00 \\
\hline 3 & Use of vermicompost & 80.00 & 75.00 & 80.00 & 73.33 \\
\hline 4 & Leaf colour chart & 76.67 & 70.00 & 76.67 & 70.00 \\
\hline 5 & $\begin{array}{l}\text { Foliar spray of } \\
\text { Pseudomonas fluorescens } \\
@ 0.2 \% \text { at } 20 \text { and } 40 \\
\text { DAP }\end{array}$ & 89.00 & 85.60 & 90.00 & 83.33 \\
\hline 6 & $\begin{array}{l}\text { Preparation of } \\
\text { panchagavya and spray }\end{array}$ & 62.00 & 53.33 & 93.33 & 86.67 \\
\hline 7 & $\begin{array}{l}\text { Spray of neem oil and } \\
\text { Neem seed kernal extract }\end{array}$ & 72.23 & 54.33 & 73.33 & 63.33 \\
\hline 8 & $\begin{array}{l}\text { Setting of yellow sticky } \\
\text { trap and pheromone trap }\end{array}$ & 70.00 & 44.00 & 70.00 & 27.14 \\
\hline 9 & $\begin{array}{l}\text { Use of egg parasites } \\
\text { Trichogramma chilonis } \\
\text { for leaf folder } \\
\text { management }\end{array}$ & 65.67 & 50.00 & 65.67 & 43.33 \\
\hline
\end{tabular}

Table.3 Yield parameters and pest and disease incidence in FFS demonstrated plot

\begin{tabular}{|l|c|c|}
\hline \multicolumn{1}{|c|}{ Parameters } & FFS demonstration plot & Farmer practice \\
\hline No of tillers/hill & 22.50 & 20.50 \\
\hline Yield (q/ha) & 66.50 & 62.25 \\
\hline B:C ratio & 1.86 & 1.65 \\
\hline Leaf folder incidence (\%) & 1.75 & 1.81 \\
\hline Stem borer incidence (\%) & 1.40 & 1.45 \\
\hline Blast disease incidence (\%) & 0.75 & 1.05 \\
\hline
\end{tabular}

The achievement of the significant mediation of the administration lies upon the improvement of attitude of the ranchers as well as the KVK staff by perceiving each other as a part of the expansion framework through standard procedure of sharing data and information. The achievements of demonstration of improved paddy package of practices through FFS were found as progressively appropriate in knowledge and adoption level of the farmers.

Field support should be extended to farmers throughout the crop season by field extension 
workers that can build more confidence among farmers and result in better adoption of technologies and thereby increasing the production and productivity levels in various crops.

\section{References}

Bunyatta, D. K., Muriethi, J. G., Anyango, C. A. and Ngesa, F. U., 2006., Farmer Field Schools effectiveness for soil and crop management technologies in Kenya . J. Int. Agri. and Ext.Edu., 13(3): 47-64.

Khisa, G. S. and Heinemann, E., 2005. Empowerment through Farmer Field
Schools. F.W.T. Penning de Vries (ed). Bright Spots Demonstrate Community Successes in African Agriculture. Working Paper 102. Colombo, Sri Lanka.

Luther, G.C., Harris, C., Sherwood, S., Gallagher, K. J., Mangan, and Gamby, K.T., 2005, Developments and Innovations in Farmer Field Schools and Training of Trainers, Globalizing IPM. Blackwell Publishing. 275 pp.

Tripp, R., Wijertne, M. and Piyadasa, V. H., 2005, what should we expect from Farmer Field Schools? A Sri Lanka Case Study. World Dev., 33(10): 17051720

\section{How to cite this article:}

Porkodi, G. and Kannan, S. 2020. Impact on Knowledge Gain through Farmer Field School (FFS) on Eco-Friendly Crop Management in Paddy. Int.J.Curr.Microbiol.App.Sci. 9(04): 17121716. doi: https://doi.org/10.20546/ijcmas.2020.904.201 